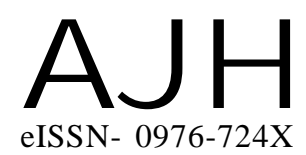

Received : 01.10.2016

Revised : 08.11 .2016

Accepted : 21.11.2016
RESEARCH PAPER

THEASIAN JOURNAL OF HORTICULTURE

Volume 11 | Issue 2 | December, 2016 | 368-372

Visit us -www.researchjournal.co.in
Members of the Research Forum

Associated Authors:

${ }^{1}$ Department of Fruit Science,

College of Horticulture and Forestry,

Central Agricultural University,

PASIGHAT (ARUNACHAL PRADESH)

INDIA

Email : romensenjam@yahoo.com

${ }^{2}$ Department of Tree Improvements, College of Horticulture and Forestry, Central Agricultural University, PASIGHAT (ARUNACHAL PRADESH) INDIA

Email : lyndoh@gmail.com

${ }^{3}$ College of Horticulture and Forestry, Central Agricultural University, PASIGHAT (ARUNACHAL PRADESH) INDIA

Email : chfdeanpsg@yahoo.com

Author for correspondence :

A.K. PHURAILATPAM

Department of Floriculture,

Medicinal and Aromatic Plants,

College of Horticulture and Forestry,

Central Agricultural University,

PASIGHAT (ARUNACHAL PRADESH)

INDIA

Email : arunkumarph@gmai.com

\section{Loranthus ligustrinus - A causal factor for Khasi mandarin (Citrus reticulata Balnco.) decline in Arunachal Pradesh}

\section{S.R. SINGH ${ }^{1}$, A.K. PHURAILATPAM, N. LYNGDOH ${ }^{2}$ AND A.K. PANDEY ${ }^{3}$}

ABSTRACT : A survey was conducted in the East Siang district of Arunachal Pradesh, India during the period 2013-2014 for the identification of Loranthus species infesting the Khasi mandarin orchards in this region. Study on its habit, mode of seed dispersion, host plants, its life cycle and its management in different sites of East Siang district was conducted. It is identified that the Loranthus species as Helixanthera ligustrina (Loranthus ligustrinus) which flowers during the month of April - May and the seed dispersal is mainly done by two birds viz., Plain flowerpecker and Fire breasted flowerpecker in June-July period. The study also revealed that it is one of the main problems causing Khasi mandarin decline by lowering down its yield and productivity and finally killed the plant after 4-5 years of infestation. This parasitic weed is slowly spreading to other nearby orchards and needs emergency attention for the citrus grower.

KEY WORDS : Helixanthera ligustrina, Khasi mandarin, Host plants, Flowerpecker

HOW TO CITE THIS ARTICLE : Singh, S.R., Phurailatpam, A.K., Lyngdoh, N. and Pandey, A.K. (2016). Loranthus ligustrinus - A causal factor for Khasi mandarin (Citrus reticulata Balnco.) decline in Arunachal Pradesh. Asian J. Hort., 11(2) : 368-372, DOI : 10.15740/HAS/TAJH/11.2/368-372. 